\title{
Dinosaur tracks from the Early Cretaceous (Albian) of Parede (Cascais, Portugal): new contributions for the sauropod palaeobiology of the Iberian Peninsula
}

\author{
V.F. Santos ${ }^{1,2 *}$, P.M. Callapez 2,3, D. Castanera ${ }^{4}$, F. Barroso-Barcenilla ${ }^{5,6}$, \\ N.P.C. Rodrigues ${ }^{1}$, C.A. Cupeto ${ }^{7}$

\begin{abstract}
${ }^{1}$ Museu Nacional de História Natural e da Ciência, Rua da Escola Politécnica 58, 1250-102 Lisboa, Portugal ${ }^{2}$ Centro de Investigação da Terra e do Espaço da UC-CITEUC, Avenida Dr. Dias da Silva, 3000-134 Coimbra, Portugal ${ }^{3}$ Departamento de Ciências da Terra da Universidade de Coimbra, Largo Marquês de Pombal, 3001-401 Coimbra, Portugal ${ }^{4}$ Grupo Aragosaurus-IUCA, Paleontología, Facultad de Ciencias, Universidad de Zaragoza, Calle Pedro Cerbuna 12, 50009 Zaragoza, Spain

${ }^{6}$ Grupo de Investigación IberCreta, Universidad de Alcalá de Henares, 28871 Alcalá de Henares, Spain

${ }^{7}$ Departamento de Geociências da Universidade de Évora, Rua Romão Ramalho 59, 7000-671 Évora, Portugal
\end{abstract} \\ ${ }^{5}$ Departamento de Paleontología, Facultad de Ciencias Geológicas, Universidad Complutense de Madrid, 28040 Madrid, Spain
}

e-mail addresses: vsantos@museus.ul.pt (V.F.S., *corresponding author); callapez@dct.uc.pt (P.M.C.); dcastanera@unizar.es (D.C.); fbarroso@geo.ucm.es (F.B.B.); nunopcrodrigues@museus.ul.pt (N.P.C.R.); cupeto@uevora.pt (C.A.C.)

Received: 17 January 2014 / Accepted: 18 December 2014 / Available online: 25 March 2015

\begin{abstract}
A recently discovered Early Cretaceous (early late Albian) dinosaur tracksite at Parede beach (Cascais, Portugal) reveals evidence of dinoturbation and at least two sauropod trackways. One of these trackways can be classified as narrow-gauge, which represents unique evidence in the Albian of the Iberian Peninsula and provides for the improvement of knowledge of this kind of trackway and its probable trackmaker, in an age when the sauropod record is scarce. These dinosaur tracks are preserved on the upper surface of a marly limestone bed that belongs to the Galé Formation (Água Doce Member, middle to lower upper Albian). The study of thin-sections of the beds C22/24 and C26 in the Parede section has revealed a microfacies composed of foraminifers, radiolarians, ostracods, corals, bivalves, gastropods, and echinoids in a mainly wackestone texture with biomicritic matrix. These assemblages match with the lithofacies, marine molluscs, echinids, and ichnofossils sampled from the section and indicate a shallow marine, inner shelf palaeoenvironment with a shallowing-upward trend. The biofacies and the sequence analysis are compatible with the early late Albian age attributed to the tracksite. These tracks and the moderate dinoturbation index indicate sauropod activity in this palaeoenvironment. Titanosaurs can be dismissed as possible trackmakers on the basis of the narrow-gauge trackway, and probably by the kidney-shaped manus morphology and the pes-dominated configuration of the trackway. Narrow-gauge sauropod trackways have been positively associated with coastal palaeoenvironments, and the Parede tracksite supports this interpretation. In addition, this tracksite adds new data about the presence of sauropod pes-dominated trackways in cohesive substrates. As the Portuguese Cretaceous sauropod osteological remains are very scarce, the Parede tracksite yields new and relevant evidence of these dinosaurs. Furthermore, the Parede tracksite is the youngest evidence of sauropods in the Portuguese record and some of the rare evidence of sauropods in Europe during the Albian. This discovery enhances the palaeobiological data for the Early Cretaceous Sauropoda of the Iberian Peninsula, where the osteological remains of these dinosaurs are relatively scarce in this region of southwestern Europe. Therefore, this occurrence is also of overall interest due to its impact on Cretaceous Sauropoda palaeobiogeography.
\end{abstract}

Keywords: Sauropod tracks, intertidal palaeoenvironment, Lower Cretaceous, upper Albian, Lusitanian Basin, Portugal

Resumen

El reciente descubrimiento de huellas de dinosaurios del Cretácico Inferior (inicio del Albiense tardío) en la playa de Parede (Cascais, Portugal) ha revelado evidencias de dinoturbación y al menos dos rastros de saurópodos. Uno de ellos puede clasificarse como estrecho y representa la única evidencia de este tipo de rastros en el Albiense de la Península Ibérica. Estos nuevos datos permiten mejorar el conocimiento tanto de este tipo de rastros como de su posible productor, en una edad en la que el registro de saurópodos es escaso. Las huellas de dinosaurios se localizan en un nivel de caliza margosa perteneciente a la Formación Galé (Miembro Água Doce, Albiense medio-base del 
superior). El estudio de láminas delgadas de los niveles C22/24 y C26 de la sección estratigráfica de Parede ha mostrado ricas biomicrofacies compuestas por foraminíferos, radiolarios, ostrácodos, corales, bivalvos, gasterópodos y equinoideos, mayoritariamente en textura "wackestone" con matriz biomicrítica. Estas asociaciones coinciden con las litofacies, los moluscos marinos, los equínidos y los icnofósiles obtenidos en la sección, y corresponden a un paleoambiente marino somero de plataforma interna con tendencia somerizante hacia techo. Las biofacies y el análisis secuencial resultan compatibles con la edad del inicio del Albiense tardío atribuida al yacimiento. Estas huellas y el moderado índice de dinoturbación son indicadores de la actividad de saurópodos en este paleoambiente. En base a la estrechez del rastro, probablemente a la morfología arriñonada/semicircular de la mano y al hecho que se trata de un rastro "pes-dominated", pueden descartarse a los titanosaurios como posibles productores. Los rastros estrechos han sido relacionados con paleoambientes costeros, y el yacimiento de Parede sustenta esta interpretación. Además, este yacimiento proporciona nuevos datos sobre la presencia de rastros de tipo "pes-dominated" en substratos cohesivos. Los restos osteológicos de saurópodos cretácicos portugueses son muy escasos, aportando el yacimiento de Parede una nueva y relevante evidencia de estos dinosaurios. Asimismo, el yacimiento de Parede constituye el hallazgo más moderno de saurópodos en el registro portugués, y una de las pocas evidencias de saurópodos en Europa durante el Albiense. Este descubrimiento incrementa los datos paleobiogeográficos de Sauropoda en el Cretácico Inferior en la Península Ibérica, en un período de tiempo en el que los restos de estos dinosaurios son escasos en esta región del Suroeste de Europa. Por tanto, este hallazgo muestra un elevado interés debido a su trascendencia para la paleobiogeografía de Sauropoda en el Cretácico.

Palabras clave: Icnitas de saurópodos, paleoambiente intermareal, Cretácico Inferior, Albiense superior, Cuenca Lusitánica, Portugal

\section{Introduction}

The sauropod track record from Portugal is well known in the ichnological literature, with significant sites from the Middle Jurassic (Santos et al., 1994, 2009) and the Late Jurassic (Lockley and Santos, 1993; Lockley et al., 1994; Mateus and Milàn, 2005, 2010). However, the Praia Grande tracksite (Sintra, near Lisboa), which is early Aptian in age, has been so far the only record of sauropod tracks in the Cretaceous of Portugal (Santos et al., 2013a). The occurrence of sauropod tracks at Praia Grande has been noted by several authors (e.g. Lockley et al., 1994; Lockley and Meyer, 2000) and the detailed description of the site can be found in the unpublished $\mathrm{PhD}$ Thesis of Santos (2003). In the same way, the Spanish sauropod ichnological record has well-known tracksites from the Late Jurassic (Lockley et al., 2007), the Jurassic-Cretaceous (Tithonian-Berriasian) transition (Sanz et al., 1997; Castanera et al., 2010a, 2010b, 2011, 2012; Pascual-Arribas and Hernández-Medrano, 2011; Alcalá et al., 2012; 2014), the Early Cretaceous (mainly pre-Albian: Moratalla et al., 2003; Pérez-Lorente, 2003; Moratalla, 2009; Castanera et al., 2013), and the Late Cretaceous (Vila et al., 2005, 2008, 2013). The Spanish tracksites from Monte Grande (Albian, near Bilbao) and Yecla (Albian, Murcia) are the only ones from the "Mid Cretaceous" (Moratalla et al., 1994; PérezLorente et al., 2006) in the entire Iberian Peninsula.

According to the classification of sauropod trackways into narrow and wide-gauge categories (Farlow, 1992; Lockley et al., 1994), the former have been considered as common during the Jurassic and scarce during the Cretaceous (Lockley et al., 1994; Wilson and Carrano, 1999; Wright, 2005; Mannion and Upchurch, 2010). Several works have associated the narrow-gauge trackways with diplodocoid or non-titanosauriform sauropods, and the wide-gauge trackways with titanosaur/titanosauriform sauropods (Lockley et al., 1994; Wilson and Carrano, 1999; Wright, 2005; Mannion and Upchurch, 2010). Furthermore, Mannion and Upchurch (2010) registered a positive correlation of narrow-gauge trackways with coastal environments, and of wide-gauge trackways

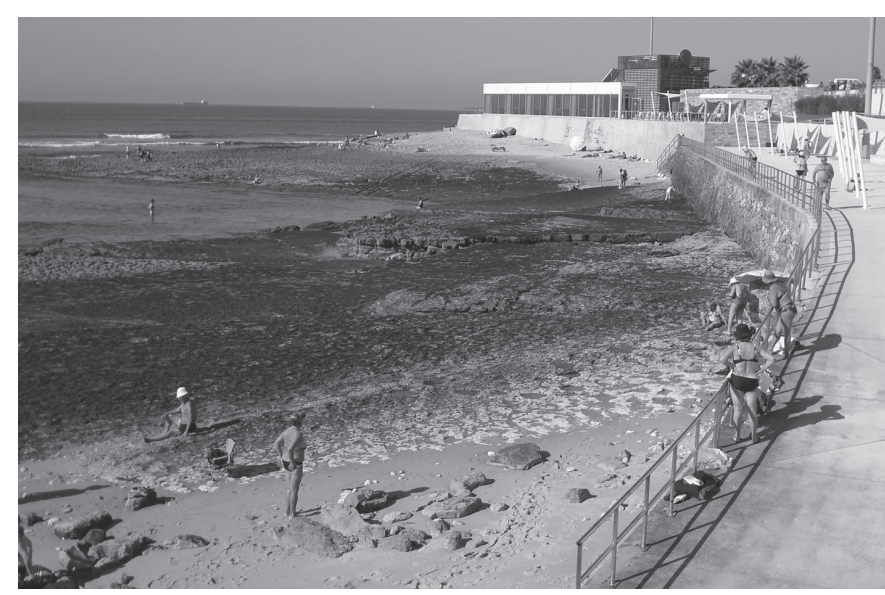

Fig. 1.- Overview of the surface with dinosaur tracks at Parede beach (early late Albian, Cascais, Portugal).

with inland environments. Significant Albian sauropod tracksites have been described in North America (Farlow et al., 1989, 2012; Pittman and Gillette, 1989; Pittman and Lockley, 1994), in Asia (Lim et al., 1989; Lee et al., 2000; Lee and Lee, 2006; Lockley et al., 2006), and in Europe (Moratalla et al., 1994; Dalla Vecchia and Tarlao, 2000; Pérez-Lorente et al., 2006). All of them have been classified into the widegauge (or intermediate category), with the exception of the sauropod trackway reported by Lee and Lee (2006) from Jageun Guhakpo, Korea (Mannion and Upchurch, 2010).

The Portuguese Cretaceous sauropod osteological record is reduced to some material from the Barremian marginalmarine beds of Boca do Chapim (north of Cabo Espichel, Sesimbra) described by Sauvage (1896, 1897-1898) and Lapparent and Zbyszewski (1957), and assigned to "Pleurocoelus" valdensis (Antunes and Mateus, 2003). The presence of this sauropod was also recognized in Spain, among other Early Cretaceous sauropods (for an overview on dinosaurs, especially sauropod remains, from the Iberian Peninsula, see: Ruiz-Omeñaca et al., 2004; Ortega et al., 2006; FCPTD, 2009; Royo-Torres, 2009; Castanera and Canudo, 2011). Despite the fact that thyreophorans have been described in 


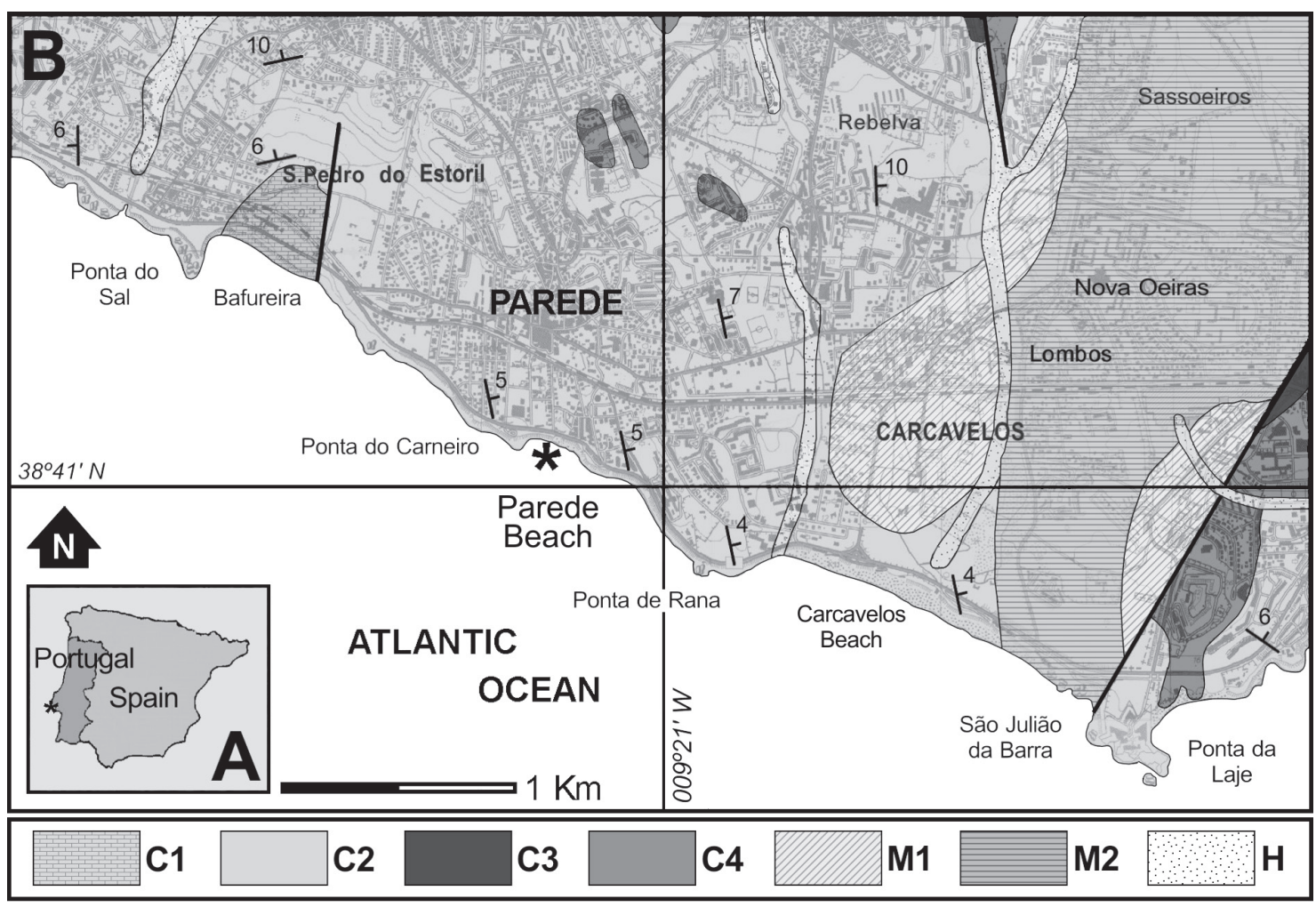

Fig. 2.- Geographical location and geological framework of the Parede dinosaur tracksite. A, Location on the Iberian Peninsula and west-central Portugal. B, Simplified sketch of the Cascais-Estoril coast, with the main outcrops of the geological units (adapted from Ramalho et al., 2001; Rey, 2006; Dinis et al., 2008). *, Location of the tracksite; C1, Upper Aptian to lower Albian alluvial siliciclastics (Rodízio Formation); C2, Middle to Upper Albian inner platform carbonates (Galé Formation); C3, Lower to upper Cenomanian platform carbonates (Caneças and Bica Formations); C4, Campanian to lower Maastrichtian basaltic flows and volcanic tuffs (Volcanic Complex of Lisbon); M1, Aquitanian marine claystones (Argilas dos Prazeres unit); M2, Lower Burdigalian marine sandstones (Areolas da Estefânia unit); $\mathrm{H}$, Holocene surface deposits.

Spain (Pereda-Suberbiola, 2006), no other quadrupedal dinosaurs, apart from sauropods, have been identified in the late Early Cretaceous of the Iberian Peninsula.

Here we describe a new Early Cretaceous (early late Albian) sauropod tracksite that has recently been discovered at the beach at Parede (Santos et al., 2012, 2013b), near Lisbon and Cascais, in west-central Portugal (Fig. 1). Apart from its scientific importance, the Parede tracksite has important educational and cultural value, since dinosaur tracksites have been considered as crucial places for the non-formal teaching and learning of geology, in general, and palaeontology, in particular.

The main goal of this paper is to provide a detailed description of the youngest sauropod tracks from the Cretaceous of Portugal, discussing their assignment within Sauropoda and emphasizing their importance due to the scarcity of narrowgauge trackways during the Cretaceous. Their overall significance and implications for the Cretaceous dinosaur ichnological/osteological record is also discussed herein, as well as their contribution to the knowledge of the palaeobiology and palaeobiogeography for the Early Cretaceous Sauropoda of the Iberian Peninsula, and of the entire southwestern Europe, in a period of time where sauropod remains are relatively scarce in this region.

\section{Geographical and geological settings}

The studied tracksite is exposed on the Atlantic rocky shore of Parede beach, within a small embayment of the Cascais-Estoril coast located in front of the village of Parede (Fig. 2), about $20 \mathrm{~km}$ west of the centre of Lisbon. This coastal area has several sandy beaches and a nearly continuous shoreline of vertical cliffs and rock falls cut in Lower Cretaceous carbonate units of the Lusitanian Basin (Ramalho et al., 1999).

The local seashore comprises a $150 \mathrm{~m}$ long sandy cover surrounded by cliff areas, with Cretaceous limestone pavements slightly dipping to the east and mostly uncovered at low tide. Specifically, the Lower Cretaceous strata consist of a $15.5 \mathrm{~m}$ thick succession of massive limestone and nodular marly limestone beds interbedded with marly interstrata (Fig. 3). These beds are part of an incompletely-exposed middle to lower upper Albian carbonate platform sequence that represents the Água Doce Member of the Galé Formation (Rey, 1992, 2006) and its upper boundary with the rudistrich Ponta da Galé Member (Dinis et al., 2002). These levels are cut in several points of the outcrop by vertical dykes of weathered basaltic rocks related to the Upper Cretaceous "Volcanic Complex of Lisbon" (Pais et al., 2006). At the 


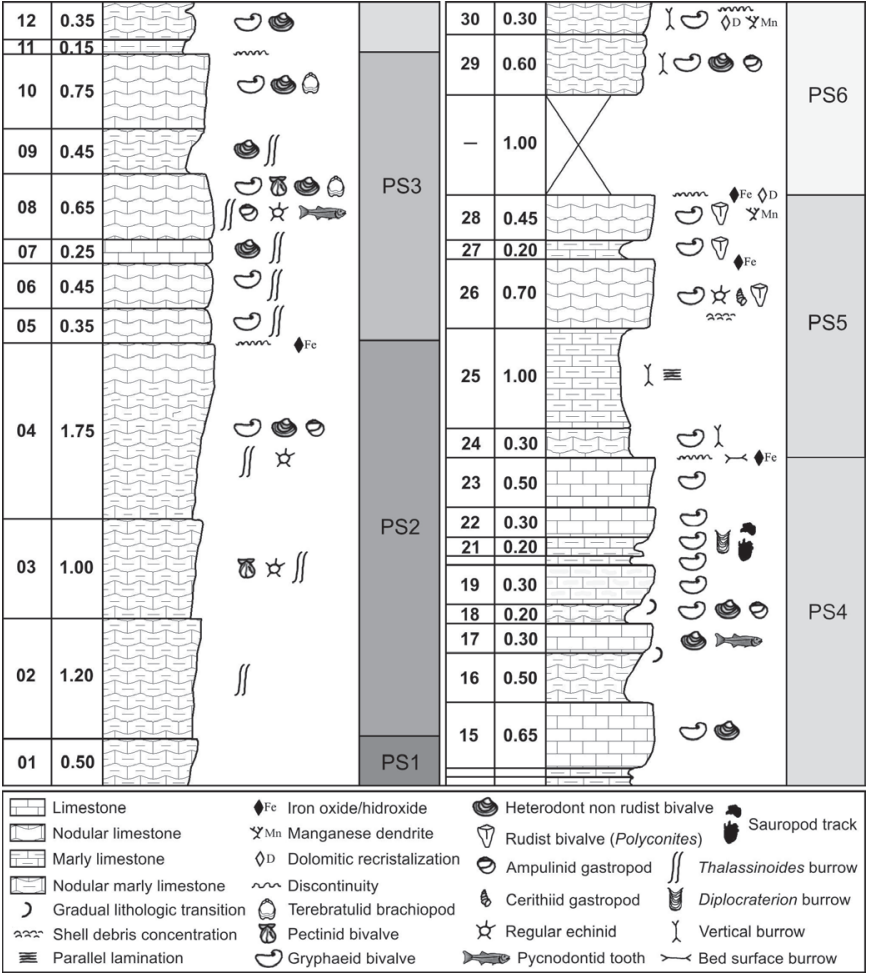

Fig. 3.- Detailed section of the Parede beach (middle to early late Albian, Galé Formation, Cascais, Portugal) with the position of the sauropod dinosaurs track level.

Parede beach, a nearly horizontal bed surface easily accessible at low tide and exposed in front of the "Terrace Bar Xana" has preserved several dinosaur tracks, which have been recently recognized after a massive sand removal induced by tidal dynamics.

Most nodular limestone beds have a rich fossil content and a few of them are densely bioturbated by Thalassinoides burrows. There is also a dense concentration of Diplocraterion in the strata immediately below the dinoturbated bed. The invertebrate macrofauna is of moderate diversity, with a dominance of pectinid (Neithea) and gryphaeid bivalves (Exogyra and Ceratostreon), and moulds of heterodontid bivalves tentatively assigned to Anisocardia, Protocardia, Fimbria, and Proveniella. Rudists are found above the dinosaur track level and at the top of the section. Here several small clusters of disarticulated Polyconites specimens can be observed. The non-rudist bivalves mentioned above occur together with scattered moulds of gastropods (Ampullina and Tylostoma), abundant echinoid spines, several Diplopodia, and an isolated pycnodontid fish tooth (Coelodus). Thin sections of beds $\mathrm{C} 22 / 24$ and $\mathrm{C} 26$ situated immediately above the track surface show, in relative abundance order, fragments of bivalves (ostreids and rudists), benthic foraminifera (Miliolidae, Lituolidae, Textularidae, Ataxofragmiidae), radiolarians (Spumellaria), ostracods, corals (Scleractinia), gastropods, and echinoids in a mainly wackestone texture with biomicritic matrix (Fig. 4).

The section of Parede beach records only a small interval of the Lower Cretaceous stratigraphic succession of the Sintra-
Cascais-Lisboa carbonate platform (Rey, 1972, 1979). The onshore sedimentary infill of this tectono-sedimentary unit of the Lusitanian Basin reaches a maximum thickness of $430 \mathrm{~m}$ in the depocentre of Cascais, where it consists of nine formations with Berriasian to Albian open shelf, reef, and lagoonal platform carbonates, interbedded with nearshore mixed carbonate-siliciclastic rocks and regressive coarse alluvial siliciclastics (Rey, 1992, 2006, 2010).

This succession, recorded by large exposures and strong lateral variations of facies, is a noteworthy setting for studies of the events occurred on the West Portuguese Continental Margin, from the Neocimerian tectonic phase (Rey et al., 2003, 2006; Rey, 2006) to a well-marked Aptian rupture (Dinis and Trincão, 1995; Dinis et al., 2002, 2008) and a final transition to a passive context, with extension of a large carbonate platform during the Cenomanian (Berthou, 1984a, 1984b; Callapez, 2008; Barroso-Barcenilla et al., 2011; Segura et al., 2014). According to Rey et al. $(2003,2006)$ and Rey (2006, 2010), three second-order depositional cycles can be identified from the upper Berriasian to the Albian, with transgressive maximums recorded at the lower Hauterivian, lower Aptian, and upper Albian, and regressive boundaries at the lower Barremian, lower upper Aptian, and Albian-Cenomanian boundary.

The Parede beach succession belongs to the lower half of the youngest of these second-order depositional cycles, where it can be correlated with the lower part of the third-order sequence "AL8" defined by Dinis et al. (2002) and Rey (2006) for the Cascais region. This means that the local stratigraphic section is above the middle-upper Albian transition, where the Knemiceras uhligi bed of the sequence "AL7" records a basal Upper Albian maximal flooding surface, followed by a regressive system tract on the overall carbonate platform. The sauropod trackways are preserved on the sedimentary tract of the subsequent transgressive phase ("AL8"), when several parasequences of inner shelf and tidal flat carbonates accumulated.

The limestone bed with Polyconites clusters lying on the top of the Parede beach section indicates the growth of small rudist buildups on the carbonate platform. This record is correlative of the upper part of "AL8" (Dinis et al., 2002) and also represents the lower boundary of the rudist-rich Ponta da Galé Member of the Galé Formation (Rey, 1992).

\section{Material and methods}

The track level at Parede beach corresponds to an extensive intertidal exposure with moderate dinosaur trampling, considering the dinoturbation index proposed by Lockley and Conrad (1989). Despite the slight erosion of these tracks, at least two quadruped trackways can be identified. The main trackway (PT1) is a sequence of at least eight subtriangular impressions (pes) and one kidney shaped impression (manus), which is crossed subperpendicularly by a poorly preserved quadruped trackway with one clear kidney-shaped impression (PT2). 
The description of the Parede trackways follows standard procedures and ichnological terminology (e.g. Leonardi, 1987; Thulborn, 1990; Lockley, 1991; Moratalla, 1993; Romano et al., 2007): track length, width, and depth, stride length, pace length, inner trackway width, total trackway width, pace angulation and footprint rotation. Heteropody was calculated using the formula [(manus length $\mathrm{x}$ manus width)/(pes length $\mathrm{x}$ pes width)* 100] proposed by Moratalla (1993). We have taken the heteropody index of the one manus-pes set that best represents the manus-pes dimensions of the main trackway (PT1). We used the formulas of Alexander (1976) to estimate hip height. Due to the poor preservation of the tracks, we have used the general morphology of the pes and manus prints as the only non-metric ichnological parameters. Due to the outcrop conditions, it was not possible to estimate some parameters such as the pes trackway ratio (Romano et al., 2007) and the width of the angulation pattern/ pace length ratio (Marty et al., 2010).

The local stratigraphic section of Parede beach was also studied in order to interpret the depositional environment and the palaeogeographical setting. Accordingly, the lithofacies and sequence analyses were followed by the determination of the invertebrate taxa found in each bed, and by a microfacies overview of the strata close to the dinoturbated surface (beds $\mathrm{C} 22 / 24$ and $\mathrm{C} 26$ ).

\section{Dinosaur tracks description and facies analysis}

An overview of the nearly horizontal track level (C21) situated at the Parede beach reveals a first sequence of quadruped footprints (PT1) (Fig. 5). This trackway is crossed and distorted by a second one (PT2) that is partially preserved, making it difficult to obtain measurements of the parameters. This ichnological occurrence becomes more evident whenever sand removal induced by tidal dynamics occurs.

The dinosaur tracks at Parede are preserved in bioclastic coarse sediment not favourable for the preservation of any anatomical features in manus and pes prints. This absence of details could be merely a consequence of the substrate conditions or the depth of preservation of the tracks. It is difficult to interpret whether the track level is the original tracking surface, so we accept that when the trackmakers passed in this area they could go through C22 sediment layer leaving their undertracks (sensu Marty et al., 2010) on the top of C21, the sedimentary layer below.

The main trackway (PT1) is a sequence of at least eight subtriangular impressions and one kidney-shaped to semicircular impression (Fig. 5B). As a result, the trackway configuration is that of a pes-dominated trackway (Marty, 2008). One additional print may belong to this trackway but there is some uncertainty (see question mark in Fig. 5B). Track depth
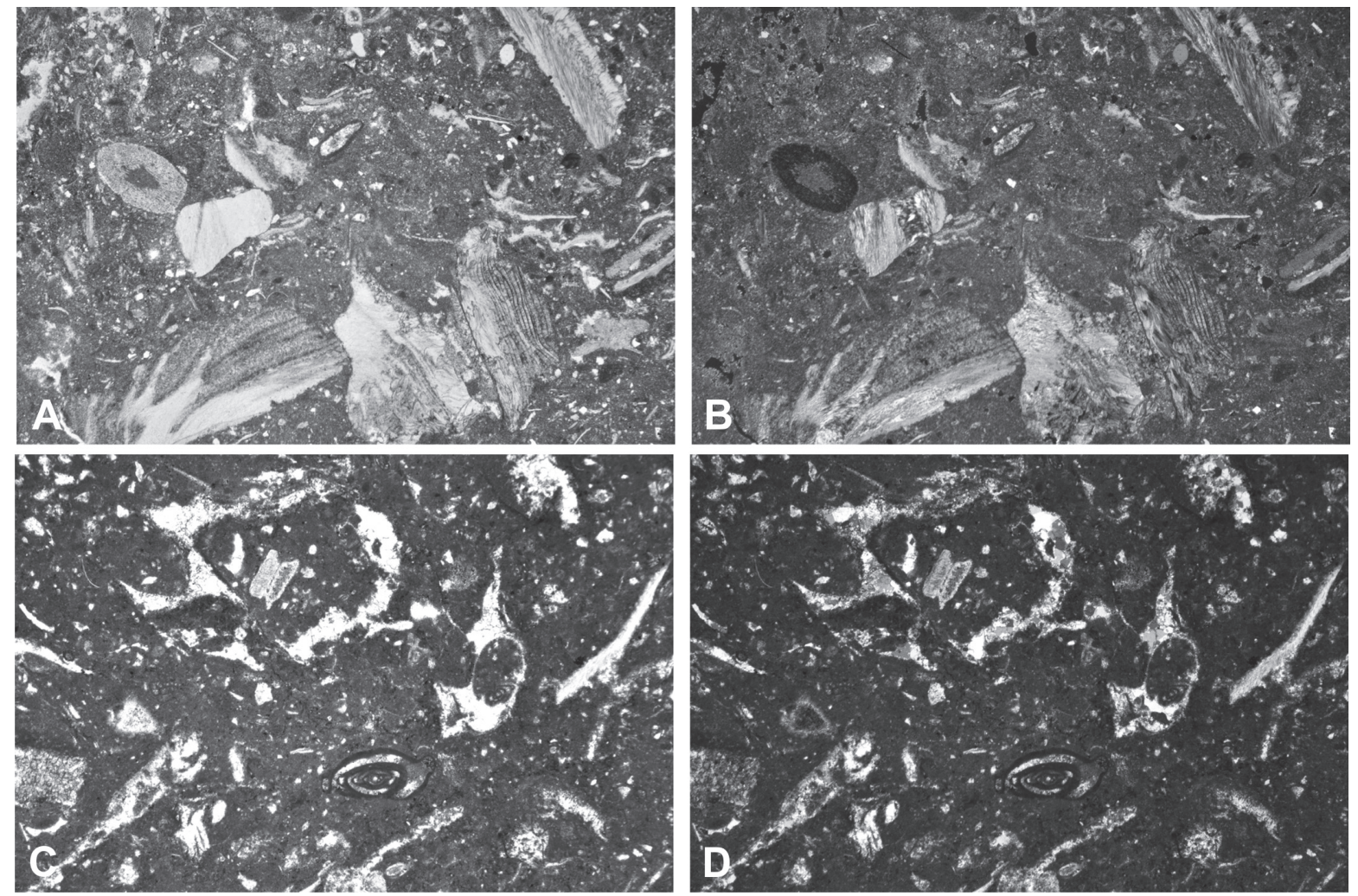

Fig. 4.- Thin sections of beds C22/24 and C26 of the Parede tracksite. A-B, Microfacies of sample C22/24 (mainly wackestone texture with biomicritic matrix) with remains of rudists (large irregular fragments), plates of echinoderms (single crystals) and ostracods, as the main elements. A, Parallel light. B, Cross-polarised light. C-D, Microfacies of sample C26, with miliolids and fischerinids (porcellaneous benthic foraminifers), textulariids (agglutinating benthic foraminifers), remains of bivalves, plates of echinoderms, and fragments of dasycladacean algae. C, Parallel light. D, Cross-polarised light. All views with Microscope Nikon Ellipse 50i (x40) and Camera Nikon D90. 

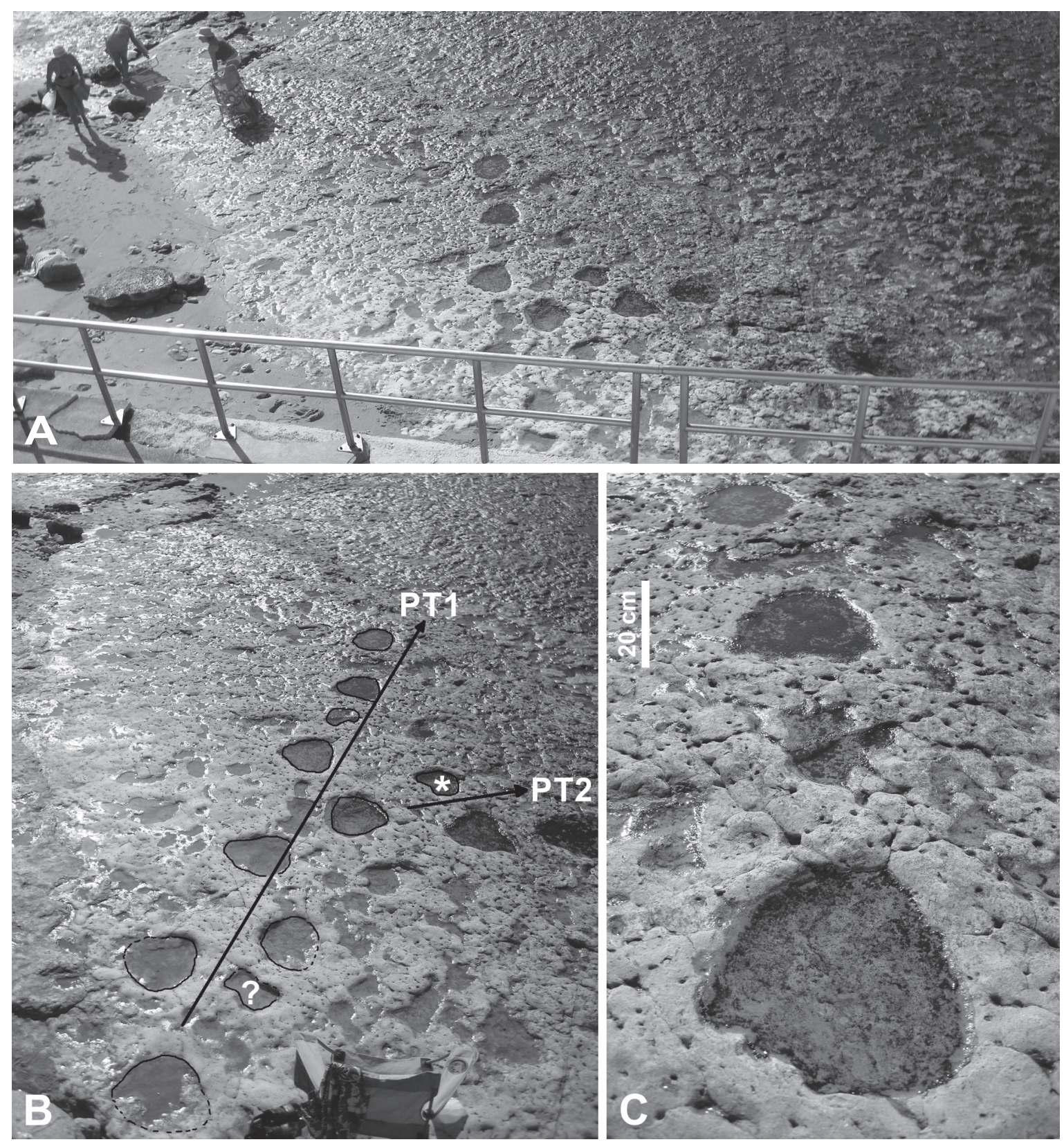

Fig. 5.- The main sauropod trackway (PT1) at Parede (early late Albian, Galé Formation, Cascais, Portugal) is crossed by another trackway (PT2), which is partially preserved and crosses and disrupts the footprint sequence of PT1. A, Photographic overview of the slab with dinosaur tracks. B, trackways PT1 and PT2; *, manus print from PT2; C, the best preserved manus-pes set of trackway PT1.

is about $2 \mathrm{~cm}$, but due to the effects of erosion, this may not be accurate. One manus-pes print set in the main trackway (PT1) indicates movement of the animal to the present-day south. The pes prints are longer than wide $(55 \mathrm{~cm}$ long by 50 $\mathrm{cm}$ wide) and subtriangular in shape, though no morphological details such as digit or claw impressions can be discerned. It is supposed that some indentations on the outer wall of the pes prints from PT1 are due to mud collapse (Fig. 5C). At the time these sauropods crossed the sediment interface, the substrate was not sufficiently firm and cohesive, allowing the walls of a footprint to slump inwards as the trackmaker pulled out its foot. The preserved manus print is wider than long $(25 \mathrm{~cm}$ long by $30 \mathrm{~cm}$ wide, $\mathrm{TL} / \mathrm{TW}=0.83)$ and kidney-shaped to semicircular. The centre of the manus print is closer to the trackway midline than the centre of the pes print. The pace length is variable and ranges from $95 \mathrm{~cm}$ to $110 \mathrm{~cm}$. Both the manus and pes prints show positive rotation of about $50^{\circ}$ relatively to the trackway midline. The inner width is no more than a few centimetres and the pes prints are close to the midline, suggesting a narrow-gauge trackway. The heteropody index is intermediate (1:3) and the pace angulation is about $90-100^{\circ}$. The hip height estimation is about $220 \mathrm{~cm}$. The glenoacetabular distance and the outer trackway width could not be estimated. This trackway is crossed by a poorly preserved quadruped trackway (PT2) represented by one clear kidney-shaped impression far from the main track- 


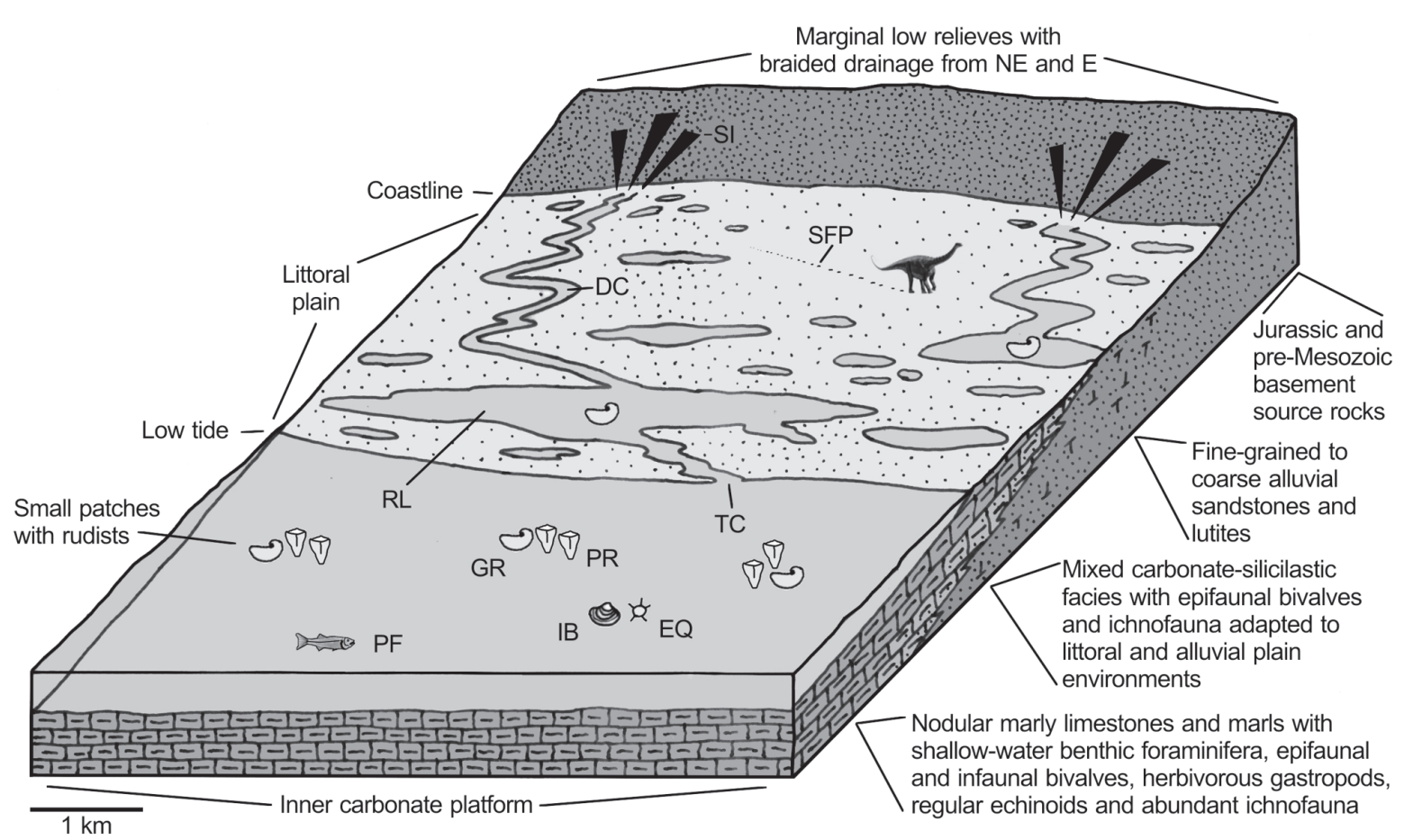

Fig. 6.- Schematic palaeoenvironmental reconstruction of the Albian carbonate platform of the Lusitanian Basin, showing an idealized tidal-flat model with combined onlap and offlap features for the sector of the Parede beach (Cascais, Portugal). SFP, sauropod dinosaur footprints and trackway; SI, siliciclastic influx; DC, distributary channels; TC, tidal channels with seawater influx; RL, lagoons and restricted lagoons; PC, Polyconites rudists; GR, epifaunal gryphaeid bivalves (Exogyra and Ceratostreon); IB, infaunal bivalves; EQ, regular echinoids; PF, pycnodontid fish.

way (Fig. 5B). There are other isolated tracks but it is not possible to associate them to either trackways PT1 and PT2. The record of dinosaur trackways preserved in stratal surfaces from shallow, low-energy, tidal-controlled sedimentary palaeoenvironments, is well documented in the Iberian Cretaceous (Santos et al., 2013a). From these other occurrences, many of the reported finds are known from marginal marine contexts close to carbonate platforms, and are often associated with transgressive episodes during the sequential evolution of some basins (e.g. Lockley and Santos, 1993; Lockley et al., 1994; Lockley and Meyer, 2000; Santos, 2003; Santos et al., 2009). The Parede section is a noteworthy example of this kind of depositional setting developed within the inner sectors of a carbonate platform (Fig. 6). Its local succession of shallow marine carbonate facies is part of a transgressivesystem tract deposited when a sea-level rise created new accommodation space for coastal sedimentation (Rey, 2006).

Both microfacies analysis of beds C22/24 and C26 and the palaeoecological requirements of the invertebrate taxa collected from several levels of the section suggest that the dinoturbation occurred in a low-energy tidal flat palaeoenvironment, close to an inner shelf opened to fully marine conditions. However, fragments of dasycladacean algae found in the carbonated microfacies indicate the relative proximity of shallow lagoons with restricted conditions.

The presence of echinoids and the abundance of articulated infaunal bivalves and Thalassinoides burrows in the lower beds of the section also indicate fully marine conditions at the palaeoenvironment, with euhaline salinity and relatively stable and oxygenated soft substrates. This fossil association changes in the uppermost beds of the section, where exogyrinid bivalves become more common and clusters of small rudists appear. The sauropod trackway occurs above a bed with dense Diplocraterion burrows, suggesting a typical tidal flat episode on the transgressive sedimentary process.

All these data match well with the ecostratigraphic and palaeogeographical models described by Rey and Cugny (1977) and Rey et al. (1977) for the Albian of the Sintra-CascaisLisboa carbonate platform.

\section{Discussion}

During the late Early Cretaceous two main groups of quadruped dinosaurs (sauropods and ankylosaurs) inhabited Europe, including the Iberian Peninsula, though the osteological record is scarce (Martin et al., 1993; Upchurch et al., 2004; Vickaryous et al., 2004; Buffetaut and Nori, 2012; Kirkland et al., 2013). Sauropod tracks are globally distributed over the entire world during the Mesozoic, with some significant tracksites in the "mid" Cretaceous in Korea and North America (Thulborn, 1990; Lockley et al., 1994; Wright, 2005; Mannion and Upchurch, 2010). By contrast, ankylosaur tracks are less well known in the ichnological literature and are restricted to the Cretaceous. They have been described in several localities from different continents, mainly in North America (McCrea et al., 2001; Lockley et al., 2006) and South America (Meyer 
et al., 2001) but also in Europe (see Petti et al., 2010; Hornung and Reich, 2014 and references therein). As concerns ankylosaur tracks morphology, the manus presents five digits arranged in a semicircular or radiating pattern and pes with four digits and a wide and elongated heel (Thulborn, 1990; McCrea et al., 2001; Petti et al., 2010). Other quadrupedal dinosaurs like stegosaurs (Galton and Upchurch, 2004) or ceratopsians (Dodson et al., 2004) have not been described yet (neither by osteological or ichnological remains) from the Aptian-Turonian of Europe, so we assume that these dinosaurs are not candidates to be the trackmakers of Parede.

As happened with sauropod and thyreophoran tracks (such as those of ankylosaurs), the distinction between them is not obvious when dealing with tracks that do not preserve anatomical characters, such as digit marks. Sacchi et al. (2009) distinguished between sauropod and ankylosaur tracks from the Aptian of Italy on the basis of heteropody and footprint rotation. Thus, according to the interpretation of these authors and of McCrea et al. (2001) and Petti et al. (2010), ankylosaur tracks have low heteropody and lower footprint rotation than the great majority of sauropod trackways (Thulborn, 1990; Wright, 2005).

Due to the arrangement of the tracks with clear outward rotation and intermediate heteropody (1/3) along the trackway PT1 at Parede, we can assume that these features are more sauropod-like than ankylosaur-like. Furthermore, the general morphology of the tracks (subtriangular pes impressions and kidney-shaped to semicircular manus impressions) is more consistent with the interpretation of a sauropod origin than an ankylosaur one. The kidney-shaped manus and the subtriangular pes morphologies have been described in other sauropod trackways that do not show digit impressions (Thulborn, 1990; Wright, 2005). The ankylosaur tracks described by Petti et al. (2010) have kidney-shaped manus tracks, though clear digit impressions are discerned. The absence of digit impressions in sauropod manus tracks is not uncommon, even in well-preserved trackways where digit impressions have been preserved in pes prints (Marty, 2008; Santos et al., 2009; Marty et al., 2010; Castanera et al., 2011, 2012, in press). As such, this absence is not a limitation to assign the footprints to Sauropoda. In fact, it could reinforce this idea.

Other interesting feature of the main trackway (PT1) is its narrower inner width. Despite the fact that some ankylosaur trackways are also narrow-gauge (Petti et al., 2010), these trackways, with intermediate to high heteropody, have been described from elsewhere and assigned to sauropod ichnotaxa like Parabrontopodus and Breviparopus (Lockley et al., 1994; Marty et al., 2010). In fact, Moratalla (2009) described narrow-gauge sauropod trackways in the lower Aptian (Enciso, Spain) from the Iberian Peninsula.

The narrower width of the trackway may also have some taxonomic implications. Wide-gauge sauropod trackways are usually assigned to titanosaurs or titanosauriforms, while narrow-gauge sauropod trackways are usually assigned to diplodocoids (Farlow, 1992; Lockley et al., 1994; Wilson and Carrano, 1999; Day et al., 2002; Wright, 2005). This distinction fits well with the global distribution of sauropod remains and the type of trackway due to the abundance of wide-gauge trackways and titanosaurs in the Cretaceous and narrow-gauge trackways and diplodocoids in the Jurassic (Lockley et al., 1994; Wilson and Carrano, 1999; Day et al., 2004; Wright, 2005). Despite the fact that the inner width (and then the type) of the trackways can change along the same trackway (Romano et al., 2007; Castanera et al., 2012), this characteristic may have a clear taxonomical implication in narrow-gauge trackways that presumably could not have been produced by titanosaurs. If the tracks of Parede are preserved as undertracks, then the inner width can also change with the depth of preservation (Jackson et al., 2009; Falkingham et al., 2010; Castanera et al., 2012), such that the trackway would have been preserved as if it were narrower. Even considering this option, the narrow width of the trackway of Parede probably would not represent a truly widegauge trackway.

Another significant character that distinguishes sauropod groups is the presence/absence and the morphology of the manus digit I claw mark (pollex). Generally, the presence of pollex marks is a feature that is not found in advanced titanosaurs (Dalla Vecchia and Tarlao, 2000; Day et al., 2004; Castanera et al., in press). The manus of the trackway PT1 apparently do not show any sign of the pollex mark, although this absence may also be a preservational consequence (Wright, 2005; Castanera et al., in press). Wright (2005) also suggested that, according to the metacarpal arrangement, neosauropods might be considered as potential trackmakers of the kidney-shaped manus impressions. In the review of the sauropod tracks of the Iberian Peninsula made by Castanera et al. (in press), it is suggested that during the "mid" and Late Cretaceous, sauropod tracks with titanosaur affinities would potentially have manus tracks with a horseshoe morphology that would show the metacarpal arrangement of an arc of $270^{\circ}$ of the derived sauropods like titanosaurs (Wright, 2005). The scarce material of manus footprints do not provide a clear conclusion about their original morphology; nonetheless, the TL/TW ratio of 0.83 is quite high. Thus, on the basis of the inner width and perhaps the manus morphology, we also can discard titanosaurs as the potential trackmakers of Parede.

The sauropod record from the Iberian Peninsula in the Albian is very scarce, based mostly on taxonomically-unidentifiable material (Canudo et al., 2004a, 2004b). To associate the trackway PT1 with a specific group of sauropods is not really prudent. Nonetheless, discarding titanosaurs, the other main group of sauropods that inhabited Europe during the late Early Cretaceous were the rebbachisaurids (Mannion et al., 2011; Torcida Fernández-Baldor et al., 2011). The morphology of rebbachisaurid tracks so far is not well understood. Apesteguía et al. (2010) associated sauropod tracks from Cenomanian-Turonian beds of the Candeleros Formation in Northern Patagonia (Argentina) to these dinosaurs, on the basis of low heteropody due to the presence of osteologi- 
cal remains in the same unit. Neither it is well-known about the type of trackway (narrow or wide gauge) that would have produced a rebbachisaurid, but considering their diplodocoid affinities, they could be considered as potentially trackmakers of the narrow-gauge trackways of the Cretaceous. Nevertheless, this hypothesis, proposed by Moratalla (2009) who suggested that rebbachisaurids might have produced narrowgauge trackways in the lower Aptian of Cameros (Spain), should be tested on the basis of osteological and ichnological remains.

Additionally, the trackway PT1 adds new data to the sauropod pes-dominated trackways in the Cretaceous. Pes-dominated trackways are those in which the forelimbs leave no (or faint) impressions, whereas the hindlimbs are well marked (Marty, 2008; Falkingham et al., 2012). The pes-dominated trackways are generally produced when the manus do not deform the substrate or by overstepping of the manus by the pes. These kinds of trackways are more likely to be produced by sauropods with a center of mass $(\mathrm{CM})$ posteriorly located (Falkingham et al., 2011, 2012). Although no predictions of the CM position have been made for rebbachisaurids or derived titanosaurs, sauropods like diplodocoids would have had a CM located more posteriorly than titanosauriforms like Brachiosaurus (Henderson, 2006; Falkingham et al., 2012). This would be another argument pointing to a nontitanosaurifom as the candidate trackmaker of Parede. Furthermore, Falkingham et al. (2012) suggested that the Cretaceous pes-dominated tracks are associated with non-cohesive substrates. As this bias is not recorded in the Jurassic, these authors interpreted that it might be related to a different sauropod bauplan and niche partitioning among sauropods as a consequence of the rise and diversification of the titanosaurs during the Cretaceous. The trackway PT1 is preserved in a cohesive substrate (marly limestone), so it does not fit with this interpretation. Nonetheless, the preservation of the tracks in a coastal environment fits with the association proposed by Mannion and Upchurch (2010), of narrow-gauge trackways with coastal environments, suggesting that non-titanosaur sauropods preferred these environments. Again, a non-titanosaur origin for the trackway PT1 could be the explanation for the presence of a pes-dominated trackway in a cohesive substrate of a coastal environment.

\section{Conclusions}

The ichnological record of the Parede tracksite presented herein is the only clear evidence for sauropods during the Early Cretaceous of Portugal. The micro- and biofacies from the Parede section in conjunction with a sequence stratigraphic correlation indicates a relative age slightly above the middle-late Albian transition. The Parede tracksite is the first occurrence of dinosaur tracks within the Galé Formation and one of the few occurrences of sauropod tracks in the Albian of the Iberian Peninsula. Moreover, it reveals the youngest evidence of sauropods in the Portuguese dinosaur record. The footprints were made by a medium-sized narrow-gauge sauropod dinosaur with probable non-titanosaur affinity that was walking on an exposed surface of a shallow marine palaeoenvironment. The Parede section is also a source of palaeobiological, palaeoecological and palaeogeographical information about this group of vertebrates from the Early to Late Cretaceous transition in the Iberian Peninsula, which will improve knowledge of the dinosaurs in the European context.

\section{Acknowledgements}

The authors acknowledge collaboration with António Carvalho and Mário Lisboa from the Câmara Municipal de Cascais. Our gratitude goes to Prof. Dr. Julio Rodríguez-Lázaro of the Universidad del País Vasco/Euskal Herriko Unibertsitatea (Spain) for the micropalaeontological study. Fieldwork was partly supported by the Centro de Investigação da Terra e do Espaço, Universidade de Coimbra, Portugal (Fundação para a Ciência e a Tecnologia) and by the research projects CGL2011-25894 and CGL2012-35199 of the Ministerio de Ciencia e Innovación (Spain). Diego Castanera also acknowledges the support of a grant from the Europa Cai-DGA program (CB 5/11). We wish to thank Ignacio Díaz-Martínez for their constructive comments on an earlier draft of the paper, and to Christian A. Meyer and David B. Weishampel for comments that improved the text editing. Technical help from Diamantino Tojo from the "Terrace Bar Xana" is gratefully acknowledged.

\section{References}

Alcalá, L., Cobos, A., Espílez, E., Gascó, F., Mampel, L., Martín Escorza, C., Royo-Torres, R. (2012): Icnitas de dinosaurios en la Formación Villar del Arzobispo de Ababuj (Teruel, España). Geogaceta 51, 35-38.

Alcalá, L., Pérez-Lorente, F., Luque, L., Cobos, A., Royo-Torres, R., Mampel, L. (2014): Preservation of dinosaur footprints in shallow intertidal deposits of the Jurassic-Cretaceous transition in the Iberian Range (Teruel, Spain). Ichnos 21, 19-31. doi: 10.1080/10420940.2013.873721.

Alexander, R.M. (1976): Estimates of speeds of dinosaurs. Nature 261, 129-130. doi: 10.1038/261129a0.

Antunes, M.T., Mateus, O. (2003): Dinosaurs of Portugal. Comptes Rendus Palevol 2, 77-95. doi: 10.1016/S1631-0683(03)00003-4.

Apesteguía, S., Gallina, P.A., Haluza, A. (2010): Not just a pretty face: anatomical peculiarities in the postcranium of rebbachisaurids (Sauropoda: Diplodocoidea). Historical Biology 22 (1-3), 165-174. doi: 10.1080/08912960903411580

Barroso-Barcenilla, F., Callapez, P.M., Ferreira Soares, A., Segura, M. (2011): Cephalopod associations and depositional sequences from the upper Cenomanian and lower Turonian of the Iberian Peninsula (Spain and Portugal). Journal of Iberian Geology 37, 9-28. doi: 10.5209/rev JIGE.2011.v37.n1.1.

Berthou, P.Y. (1984a): Albian-Turonian stage boundaries and subdivisions in the Western Portuguese Basin, with special emphasis on the Cenomanian-Turonian boundary in the ammonite facies and rudist facies. Bulletin of the Geological Society of Denmark 33, 41-45.

Berthou, P.Y. (1984b): Résumé synthétique de la stratigraphie et de la paléogéographie du Crétacé moyen et supérieur du bassin occidental 
portugais. Geonovas 7, 99-120.

Buffetaut, E., Nori, L. (2012): Dinosaur remains from the "Sables Verts" (Early Cretaceous, Albian) of the eastern Paris Basin. In: P. Godefroit (ed.), Bernissart dinosaurs and Early Cretaceous terrestrial ecosystems. Indiana University Press, Bloomington, pp. 363-377.

Callapez, P.M. (2008): Palaeobiogeographic evolution and marine faunas of the mid-Cretaceous Western Portuguese Carbonate Platform. Thalassas 24, 29-52.

Canudo, J.I., Ruiz-Omeñaca, J.I., Ramo, A. del, Guillén Mondéjar, F. (2004a): Primera evidencia de restos de dinosaurio en Murcia (Cretácico Inferior, Albiense). Geogaceta 35, 119-122.

Canudo, J.I., Ruiz-Omeñaca, J.I., Sender, L.M. (2004b): Primera evidencia de un dinosaurio saurópodo en la Formación Escucha (Utrillas, Teruel), Albiense medio (Cretácico inferior). Geo-Temas 6(5), 27-30.

Castanera, D., Canudo, J.I. (2011): Los saurópodos del intervalo Jurásico-Cretácico de la Cordillera Ibérica: icnitas vs huesos. In: A. Pérez-García, F. Gascó, J.M. Gasulla, F. Escaso (eds.), Viajando a Mundos Pretéritos. Ayuntamiento de Morella, Morella - Castellón, pp. 101-110.

Castanera, D., Barco, J.L., Canudo, J.I., Pascual, P. (2010a): Aproximación a la diversidad de morfotipos de icnitas de saurópodo en la aloformación Huérteles (Berriasiense) en Soria (España). In: M. Moreno-Azanza, I. Díaz-Martínez, J.M. Gasca, M. Melero-Rubio, R. Rabal-Garcés, V. Sauqué (coords.), Actas del VIII Encuentro de Jóvenes Investigadores en Paleontología. Cidaris 30, 91-97.

Castanera, D., Canudo, J.I., Díaz-Martínez, I., Herrero Gascón, J., Pérez-Lorente, F. (2010b): Grandes contramoldes de icnitas de saurópodos en el Tithónico-Berriasiense de la Formación Villar del Arzobispo en Galve (Teruel). Resúmenes del V Congreso del Jurásico de España, Colunga, Asturias, pp. 178-183.

Castanera, D., Barco, J.L., Díaz-Martínez, I., Herrero-Gascón, J., PérezLorente, F., Canudo, J.I (2011): New evidence of a herd of titanosauriform sauropods from the lower Berriasian of the Iberian range (Spain). Palaeogeography, Palaeoclimatology, Palaeoecology 310, 227-237. doi: 10.1016/j.palaeo.2011.07.015.

Castanera, D., Pascual, C., Canudo, J.I., Hernández, N., Barco, J.L. (2012): Ethological variations in gauge in sauropod trackways from the Berriasian of Spain. Lethaia 45, 476-489. doi: 10.1111/j.15023931.2012.00304.x.

Castanera, D., Pascual, C., Canudo, J.I. (2013): Primera evidencia de la morfología del pie en saurópodos en el Grupo Urbión del Cretácico Inferior de la Cuenca de Cameros (Soria). Geogaceta 53, 13-16.

Castanera, D., Santos, V.F., Piñuela, L., Pascual, C., Vila, B., Canudo, J.I, Moratalla, J.J. (in press): Iberian sauropod tracks through time: variations in sauropod manus and pes morphologies. In: Richter, A., Manning, P. (Eds.), Dinosaur Tracks, Next Steps. Indiana University Press, Bloomington.

Dalla Vecchia, F.M., Tarlao, A. (2000): New dinosaur track sites in the Albian (Early Cretaceous) of the Istrian Peninsula (Croatia). Parte II Paleontology. Memorie di Scienze Geologiche 52, 227-292.

Day, J.J., Upchurch, P., Norman, D.B., Gale, A.S., Powell, P. (2002): Sauropod trackways, evolution, and behavior. Science 296, 1659. doi: 10.1126/science. 1070167.

Day, J.J., Norman, D.B., Gale, A.S., Upchurch, P., Powell, P. (2004): A Middle Jurassic dinosaur trackway site from Oxfordshire, UK. Palaeontology 47, 319-348. doi: 10.1111/j.0031-0239.2004.00366.x.

Dinis, J.L., Trincão, P. (1995): Recognition and stratigraphical significance of the Aptian unconformity in the Lusitanian Basin, Portugal. Cretaceous Research 16, 171-186. doi: 10.1006/cres.1995.1014.

Dinis, J.L., Rey, J., Graciansky, P.C. de. (2002): Le Bassin lusitanien (Portugal) à l'Aptien supérieur-Albien: organisation séquentielle, proposition de corrélations, évolution. Comptes Rendus Geoscience 334, 757-764. doi: 10.1016/S1631-0713(02)01815-1.

Dinis, J.L., Rey, J., Cunha, P.P., Callapez, P.M., Pena dos Reis, R.
(2008): Stratigraphy and allogenic controls on the western Portugal Cretaceous: an updated synthesis. Cretaceous Research 29, 772-780. doi: 10.1016/j.cretres.2008.05.027.

Dodson, P., Forster, C.A., Sampson, S.D. (2004): Ceratopsidae. In: D.B. Weishampel, P. Dodson, H. Osmólska (eds.), The Dinosauria, $2^{\text {nd }}$ edition. University of California Press, Berkeley, pp. 494-513.

Falkingham, P.L., Margetts, L., Manning, P.L. (2010): Fossil vertebrate tracks as palaeopenetrometers: confounding effects of foot morphology. Palaios 25, 356-360. doi: 10.2110/palo.2009.p09-164r.

Falkingham, P.L., Bates, K.T., Margetts, L., Manning, P.L. (2011): Simulating sauropod manus-only trackway formation using finite-element analysis. Biology Letters 7, 142-145. doi: 10.1098/rsbl.2010.0403.

Falkingham, P.L., Bates, K.T., Mannion, P.D. (2012): Temporal and palaeoenvironmental distribution of manus-and pes-dominated sauropod trackways. Journal of the Geological Society 169, 365-370. doi: 10.1144/0016-76492011-019.

Farlow, J.O. (1992): Sauropod tracks and trackmarkers: integrating the ichnological and skeletal records. Zubia 10, 89-138.

Farlow, J.O., Pittman, J.F., Hawthorne, J.M. (1989): Brontopodus birdi, Lower Cretaceous Sauropod footprints from the U.S. Gulf Coastal Plain. In: D.D. Gillette, M.G. Lockley (eds.), Dinosaur Tracks and Traces. Cambridge University Press, Cambridge, pp. 371-393.

Farlow, J.O., O’Brien, M., Kuban, G.J., Dattilo, B.F., Bates, K.T., Falkingham, P.L., Piñuela, L., Rose, A., Freels, A., Kumagai, C., Libben, C., Smith, J., Whitcraft, J. (2012): Dinosaur Tracksites of the Paluxy River Valley (Glen Rose Formation, Lower Cretaceous), Dinosaur Valley State Park, Somervell County, Texas. In: P. Huerta Hurtado, F. Torcida Fernández-Baldor, J.I. Canudo Sanagustín (eds.), Actas $V$ Jornadas Internacionales sobre Paleontología de Dinosaurios y su Entorno, Salas de los Infantes, Burgos, pp. 41-69.

FCPTD (Fundación Conjunto Paleontológico de Teruel-Dinópolis) (coord.) (2009): Icnitas de dinosaurio de la Península Ibérica, World Heritage Candidacy. Ministerio de Cultura de España, Ministério do Ambiente, do Ordenamento do Território e do Desenvolvimiento Regional de Portugal, 460 p. (unpublished)

Galton, P.M., Upchurch, P. (2004): Stegosauria. In: D.B. Weishampel, P. Dodson, H. Osmólska (eds.), The Dinosauria, $2^{\text {nd }}$ edition. University of California Press, Berkeley, pp. 343-362.

Henderson, D.M. (2006): Burly gaits: centers of mass, stability, and the trackways of sauropod dinosaurs. Journal of Vertebrate Paleontology 26, 907-921. doi: 10.1671/0272-4634.

Hornung, J.J., Reich, M. (2014): Metatetrapous valdensis Nopcsa, 1923 and the presence of ankylosaur tracks (Dinosauria: Thyreophora) in the Berriasian (Early Cretaceous) of Northwestern Germany. Ichnos 21, 1-18. doi: 10.1080/10420940.2013.873720.

Jackson, S.J., Whyte, M.A., Romano, M. (2009): Laboratory-controlled simulations of dinosaur footprints in sand: a key to understanding vertebrate track formation and preservation. Palaios 24, 222-238. doi: 10.2110/palo.2007.p07-070r.

Kirkland. J., Alcalá, L., Loewen, M., Espílez, E., Mampel, L., Wiersma, J. (2013): The basal nodosaurid ankylosaur Europelta carbonensis n. gen., n. sp. from the Lower Cretaceous (Lower Albian) Escucha Formation of Northeastern Spain. PLoS ONE 8 (12), e80405. doi: 10.1371/journal.pone.0080405.

Lapparent, A.F., Zbyszewsky, G. (1957): Les Dinosauriens du Portugal. Memórias dos Serviços Geológicos de Portugal N.S. 2 , 63 p.

Lee, Y.N., Lee, H.J. (2006): A sauropod trackway in Donhae-Myeon, Goseong County, south Gyeongsang Province, Korea and its paleobiological implications of Uhangri manus-only sauropod tracks. In: Y.N. Lee (ed.), Proceedings of the 2006 Goseong International Dinosaur Symposium. Journal of the Paleontological Society of Korea 22, 1-14.

Lee, Y.N., Yang, S.J., Seo, S.J., Baek, K.S., Yi, M.S., Lee, D.J., Park, E.J., Han, S.W. (2000): Distribution and paleobiological significance 
of dinosaur tracks from the Jindong Formation (Albian) in Kosong County, Korea. In: Y.N. Lee (ed.), International Dinosaur Symposium for Kosong County in Korea. Journal of the Paleontological Society of Korea Special Publication 4, 1-12.

Leonardi, G. (ed.) (1987): Glossary and Manual of Tetrapod Palaeoichnology. Departamento Nacional da Produção Mineral, Brasília, 117 p.

Lim, S.K., Yang, S.Y., Lockley, M.G. (1989): Large dinosaur footprint assemblages from the Cretaceous Jindong Formation of Southern Korea. In: D.D. Gillette, M.G. Lockley (eds.), Dinosaur Tracks and Traces. Cambridge University Press, Cambridge, pp. 333-336.

Lockley, M.G. (1991): Tracking Dinosaurs: A New Look at an Ancient World. Cambridge University Press, Cambridge, $238 \mathrm{p}$

Lockley, M.G., Conrad, K. (1989): The paleoenvironmental context, preservation and paleoecological significance of dinosaur tracksites in the western USA. In: D.D. Gillette, M.G. Lockley (eds.), Dinosaur Tracks and Traces. Cambridge University Press, Cambridge, pp. 121-134

Lockley, M.G., Meyer, C.A. (2000): Dinosaur tracks and other fossil footprints of Europe. Columbia University Press, New York, 323 p.

Lockley, M.G., Santos, V.F. (1993): A preliminary report on sauropod trackways from the Avelino site, Sesimbra region, Upper Jurassic, Portugal. Gaia 6, 38-42.

Lockley, M.G., Meyer, C.A., Hunt, A.P., Lucas, S.G. (1994): The distribution of sauropod tracks and trackmakers. Gaia 10, 233-248.

Lockley, M.G., Holbrook, J., Kukihara, R., Matsukawa, M. (2006): An ankylosaur-dominated dinosaur tracksite in the Cretaceous Dakota Group of Colorado: paleoenvironmental and sequence stratigraphic context. In: Lucas, S.G., Sullivan, R.M. (Eds.), Late Cretaceous Vertebrates from the Western Interior. New Mexico Museum of Natural History and Science Bulletin 35, 95-104.

Lockley, M.G., Lires, J., García-Ramos, J.C., Piñuela, L., Avanzini, M. (2007): Shrinking the world's largest dinosaur tracks: Observations of the Ichnotaxonomy of Gigantosauropus asturiensis and Hispanosauropus hauboldi from the Upper Jurassic of Asturias, Spain. Ichnos 14, 247-255. doi: 10.1080/10420940601050048.

Mannion, P.D., Upchurch, P. (2010): A quantitative analysis of environmental associations in sauropod dinosaurs. Paleobiology 36, 253282. doi: $10.1666 / 08085.1$.

Mannion, P.D., Upchurch, P., Hutt, S. (2011): New rebbachisaurid (Dinosauria: Sauropoda) material from the Wessex Formation (Barremian, Early Cretaceous), Isle of Wight, United Kingdom. Cretaceous Research 32, 774-780. doi:10.1016/j.cretres.2011.05.005.

Martin, V., Le Loeuff, J., Buffetaut, E. (1993): A sauropod dinosaur in the Middle Albian of Pargny-Sur-Saulx (Meuse, eastern France). Revue de Paléobiologie 7, 119-124.

Marty, D. (2008): Sedimentology, taphonomy, and ichnology of Late Jurassic dinosaur tracks from the Jura carbonate platform (ChevenezCombe Ronde tracksite, NW Switzerland): insights into the tidal-flat palaeoenvironment and dinosaur diversity, locomotion, and palaeoecology. GeoFocus 21, 1-278.

Marty, D., Belvedere, M., Meyer, C.A., Mietto, P., Paratte, G., Lovis, C., Thüring, B. (2010): Comparative analysis of Late Jurassic sauropod trackways from the Jura Mountains (NW Switzerland) and the central High Atlas Mountains (Morocco): implications for sauropod ichnotaxonomy. Historical Biology 22, 109-133. doi: 10.1080/08912960903503345.

Mateus, O., Milàn J. (2005): Ichnological evidence for giant ornithopod dinosaurs in the Late Jurassic Lourinhã Formation, Portugal. Abstracts of the International Symposium on Dinosaurs and other Vertebrates Palaeoichnology, Fumanya-St Corneli, Barcelona, p. 60.

Mateus, O., Milàn, J. (2010): A diverse Upper Jurassic dinosaur ichnofauna from central-west Portugal. Lethaia 43, 245-257. doi: 10.1111/j.1502-3931.2009.00190.x.

McCrea, R., Lockley, M.G., Meyer, C.A. (2001): Global distribution of purported ankylosaur track occurrences. In: K. Carpenter (ed.), The Armored Dinosaurs. Indiana University Press, Bloomington and Indianopolis, pp. 413-454.

Meyer, C.A., Hippler, D., Lockley, M.G. (2001): The Late Cretaceous vertebrate ichnofacies of Bolivia - facts and implications. In: H.A. Leanza (ed.), VII International Symposium on Mesozoic Terrestrial Ecosystems. Asociación Paleontológica Argentina, Buenos Aires, Publicación Especial 7, pp. 133-138.

Moratalla, J.J. (1993): Restos indirectos de dinosaurios del registro español: paleoicnología de la Cuenca de Cameros (Jurásico superior e Cretácico inferior) y paleoología del Cretácico superior. Unpublished Ph. D. Thesis, Universidad Autónoma de Madrid, Madrid, 729 p.

Moratalla, J.J. (2009): Sauropod tracks of the Cameros Basin (Spain): identification, trackway patterns and changes over the Jurassic-Cretaceous. Geobios 42, 797-811. doi: 10.1016/j.geobios.2009.06.006.

Moratalla, J.J., García-Mondéjar, J., Santos, V.F. dos, Lockley, M.G., Sanz, J.L., Jimenez, S. (1994): Sauropod trackways from the Lower Cretaceous of Spain. Gaia 10, 75-83.

Moratalla, J.J., Hernán, J., Jiménez, S. (2003): Los Cayos dinosaur tracksite: an overview on the Lower Cretaceous ichno-diversity of the Cameros Basin (Cornago, La Rioja Province, Spain). Ichnos 10, 229-240. doi: 10.1080/10420940390255547.

Ortega, F., Escaso, F., Gasulla, J.M., Dantas, P.M., Sanz, J.L. (2006): Dinosaurios de la Península Ibérica. Estudios Geológicos 62, 219-240. doi:10.3989/egeol.0662122.

Pais, J., Moniz, C., Cabral, J., Cardoso, J., Legoinha, P., Machado, S., Morais, M.A., Lourenço, C., Ribeiro, M.L., Henriques, P., Falé, P. (2006): Notícia explicativa da Folha 34-D (Lisboa). Carta Geológica de Portugal à escala 1:50.000. Instituto Geológico e Mineiro, Lisboa, 74 p.

Pascual-Arribas, C., Hernández-Medrano, N. (2011): Nuevos datos sobre el yacimiento icnítico de Las Cuestas I (Santa Cruz de Yanguas, Soria, España). Studia Geologica Salmanticensia 46, 121-157.

Pereda-Suberbiola, X. (2006): El dinosaurio acorazado Polacanthus del Cretácico Inferior de Europa y el estatus de los Polacanthidae (Ankylosauria). In: Colectivo Arqueolólogico-Paleontológico Salense (ed.), Actas de las III Jornadas Internacionales sobre Paleontología de Dinosaurios y su Entorno, Salas de los Infantes, Burgos, pp. 85-104.

Pérez-Lorente, F. (2003): Icnitas de dinosaurios del Cretácico en España. In: F. Pérez-Lorente (ed.), Dinosaurios y otros reptiles mesozoicos de España, Instituto de Estudios Riojanos (IER), Logroño. Ciencias de la Tierra 26, 49-108.

Pérez-Lorente, F., Guillén-Mondéjar, F., Ramo, A. del (2006): Primeras icnitas de dinosaurio en Murcia (Albiense de Yecla). Geogaceta 39, 147-150.

Petti, F.M., D’Orazi Porchetti, S., Sacchi, E., Nicosia, U. (2010): A new purported ankylosaur trackway in the Lower Cretaceous (lower Aptian) shallow-marine carbonate deposits of Puglia, southern Italy. Cretaceous Research 31, 546-552. doi: 10.1016/j.cretres.2010.07.004.

Pittman, J.G., Gillette, D.D. (1989): The Briar Site: A new sauropod dinosaur tracksite in lower Cretaceous beds of Arkansas, USA. In: D.D. Gillette, M.G. Lockley (eds.), Dinosaur Tracks and Traces. Cambridge University Press, Cambridge, pp. 135-153.

Pittman, J.G., Lockley, M.G. (1994): A review of sauropod dinosaur tracksites of the Gulf of Mexico basin. Gaia 10, 95-108.

Ramalho, M., Ribeiro, M.L., Serralheiro, A., Moitinho de Almeida, F. (1999): Carta Geológica 34-C (Cascais). Carta Geológica de Portugal à escala 1:50.000. Instituto Geológico e Mineiro, Lisboa.

Ramalho, M., Rey, J., Zbyszewski, G., Matos Alves, C.A., Palácios, T., Moitinho de Almeida, F., Costa, C., Kullberg, M. (2001): Notícia explicativa da Folha 34-C (Cascais). Carta Geológica de Portugal à escala 1:50.000. Instituto Geológico e Mineiro, Lisboa.

Rey, J. (1972): Recherches géologiques sur le Crétacé inférieur de l'Estremadura (Portugal). Memórias dos Serviços Geológicos de Por- 
tugal 21, 1-477.

Rey, J. (1979): Le Crétacé inférieur de la marge atlantique portugaise: Biostratigraphie, organisation séquentielle, évolution paléogéographique. Ciências da Terra 5, 97-121.

Rey, J. (1992): Les unités lithostratigraphiques du Crétacé inférieur de la région de Lisbonne. Comunicações dos Serviços Geológicos de Portugal 78, 103-124.

Rey, J. (2006): Stratigraphie séquentielle et séquences de dépôt dans le Crétacé Inférieur du Bassin Lusitanien. Ciências da Terra Número Especial 6, 1-120.

Rey, J. (2010): La dynamique sédimentaire des Bassins Lusitanien et de l'Algarve au Crétacé Inférieur. Ciências da Terra 17, 45-52.

Rey, J., Cugny, P. (1977): Ecoséquences et paléoenvironnements de l'Albien du Portugal. Bulletin de la Société d'Histoire Naturelle de Toulouse 113, 374-386.

Rey, J., Bilotte, M., Peybernes, B. (1977): Analyse biostratigraphique et paléontologique de l'Albien marin d'Estremadura (Portugal). Géobios 10, 369-393. doi : 10.1016/S0016-6995(77)80025-9.

Rey, J., Graciansky, P.C. de, Jacquin, T. (2003): Les séquences de dépôt dans le Crétacé inférieur du Bassin Lusitanien. Comunicações do Instituto Geológico e Mineiro 90, 15-42.

Rey, J., Dinis, J.L., Callapez, P.M., Cunha, P.P. (2006): Da rotura continental à margem passiva. Composição e evolução do Cretácico de Portugal. Cadernos de Geologia de Portugal. INETI, Lisboa, 75 p.

Romano, M., Whyte, M.A., Jackson, S.J. (2007): Trackway ratio: a new look at trackway gauge in the analysis of quadrupedal dinosaur trackways and its implications for icnotaxonomy. Ichnos 14, 257-270. doi: 10.1080/10420940601050014.

Royo-Torres, R. (2009): Los dinosaurios saurópodos en la Península Ibérica. In: P. Huerta, F. Torcida Fernández-Baldor (eds.), Actas de las IV Jornadas Internacionales sobre Paleontología de Dinosaurios y su Entorno, Salas de los Infantes, Burgos, pp. 139-166.

Ruiz-Omeñaca, J.I., Canudo, J.I., Aurell, M., Badenas, B., Cuenca-Bescós, G., Ipas, J. (2004): Estado de las investigaciones sobre los vertebrados del Jurásico superior y el Cretácico inferior de Galve (Teruel). Estudios Geológicos, 60, 179-202.

Sacchi, E., Conti, M.A., D’Orazi Porchetti, S., Logoluso, A., Nicosia, U., Perugini, G., Petti, F.M. (2009): Aptian dinosaur footprints from the Apulian platform (Bisceglie, Southern Italy) in the framework of periadriatic ichnosites. Palaeogeography, Palaeoclimatology, Palaeoecology 271, 104-116. doi: 10.1016/j.palaeo.2008.09.018.

Santos, V.F. (2003): Pistas de dinossáurio no Jurássico-Cretácico de Portugal. Considerações paleobiológicas e paleoecológicas. Unpublished Ph. D. Thesis, Universidad Autónoma de Madrid, Madrid, 365 p.

Santos, V.F., Lockley, M.G., Meyer, C.A., Carvalho, J., Galopim de Carvalho, A.M., Moratalla, J.J. (1994): A new sauropod tracksite from the Middle Jurassic of Portugal. Gaia 10, 5-13.

Santos, V.F., Moratalla, J.J., Royo-Torres, R. (2009): New sauropod trackways from the Middle Jurassic of Portugal. Acta Palaeontologica Polonica 54, 409-422. doi: 10.4202/app.2008.0049.

Santos, V.F., Castanera, D., Callapez, P.M., Cupeto, C. (2012): Dinossáurios na praia da Parede. Agenda Cultural de Cascais 55, 4-7.

Santos, V.F., Callapez, P.M., Rodrigues, N.P.C. (2013a): Dinosaur footprints from the Lower Cretaceous of the Algarve Basin (Portugal):
New data on the ornithopod palaeoecology and palaeobiogeography of the Iberian Peninsula. Cretaceous Research 40, 158-169. doi: 10.1016/ j.cretres.2012.07.001.

Santos, V.F., Castanera, D., Barroso-Barcenilla, F., Callapez, P.M., Cupeto, C.A., Rodrigues, N.P.C. (2013b): Sauropod tracks from the Lower Cretaceous of Parede beach (Cascais, Portugal). In: P. Huerta, F. Torcida Fernández-Baldor (eds.), Actas de las VI Jornadas Internacionales sobre Paleontología de Dinosaurios y su Entorno, Salas de los Infantes, Burgos, pp. 120-122.

Sanz, J.L., Moratalla, J.J., Rubio, J.L., Fuentes, C., Meijide, M. (1997): Huellas de dinosaurios de Castilla y León. Junta de Castilla y León, Valladolid, $87 \mathrm{p}$.

Sauvage, H.E. (1896): Les crocodiliens et les dinosauriens des terrains mésozoïques du Portugal. Bulletin de la Société Géologique de France 24, 46-49.

Sauvage, H.E. (1897-1898): Vertébrés fossiles du Portugal. Mémoires de la Direction des Travaux Géologiques du Portugal, 46 p.

Segura, M., Barroso-Barcenilla, F., Callapez, P., García-Hidalgo, J.F., Gil, J. (2014): Depositional sequences and cephalopod assemblages in the upper Cenomanian-lower Santonian of the Iberian Peninsula (Spain and Portugal). Geologica Acta 12, 19-27. doi: 10.1344/105.000002056.

Thulborn, R.A. (1990): Dinosaur Tracks. Chapman and Hall, London, $410 \mathrm{p}$.

Torcida Fernández-Baldor, F., Canudo, J.I., Huerta, P., Montero, D., Pereda Suberbiola, X., Salgado, L. (2011): Demandasaurus darwi$n i$, a new rebbachisaurid sauropod from the Early Cretaceous of the Iberian Peninsula. Acta Palaeontologica Polonica 56, 535-552. doi: 10.4202/app.2010.0003.

Upchurch, P., Barrett, P.M., Dodson, P. (2004): Sauropoda. In: D.B. Weishampel, P. Dodson, H. Osmólska (eds.), The Dinosauria, $2^{\text {nd }}$ edition. University of California Press, Berkeley, pp. 259-322.

Vickaryous, M.K., Maryańska, T., Weishampel, D.B. (2004): Ankylosauria. In: D.B. Weishampel, P. Dodson, H. Osmólska (eds.), The Dinosauria, $2^{\text {nd }}$ edition. University of California Press, Berkeley, pp. 363-392.

Vila, B., Oms, O., Galobart, A. (2005): Manus only titanosaurid trackway from Fumanya (Maastrichtian, Pyrenees): further evidence for an underprint origin. Lethaia 38, 211-218. doi: 10.1080/00241160510013312.

Vila, B., Oms, O., Marmi, J., Galobart, À. (2008): Tracking Fumanya footprints (Maastrichtian, Pyrenees): historical and ichnological overview. Oryctos 8, 115-130.

Vila, B., Oms, O., Galobart, À., Bates, K.T., Egerton, V.M., Manning, P.L. (2013): Dynamic similarity in titanosaur sauropods: ichnological evidence from the Fumanya dinosaur tracksite (southern Pyrenees). PLoS ONE 8(2), e57408. doi: 10.1371/journal.pone.0057408.

Wilson, J.A., Carrano, M.T. (1999): Titanosaurs and the origin of "widegauge" trackways: a biomechanical and systematic perspective on sauropod locomotion. Paleobiology 25, 252-267.

Wright, J.L. (2005): Steps in understanding sauropod biology: the importance of sauropod tracks. In: K.A. Curry Rogers, J.A. Wilson (eds.), The Sauropods: Evolution and Paleobiology. University of California Press, Berkeley, pp. 252-284. 